\section{Quibbling}

Conservationists throughout Europe see this kind of quibbling as symptomatic of a deep-rooted and stubborn refusal to face up to the problem of dying forests, despite the majority concern that has been voiced in opinion polls in many countries-including conservation-conscious Switzerland.

'There is still a part of the population that refuses to accept the reality, now proven at the European level,' says Professor Goeldlin. 'They refuse to accept it for several reasons, including its complexity and the fact [that] there has been lack of really good information. But the problem is much broader than simply the death of the forests.'

Professor Goeldlin points out that sulphur and nitric oxide emissions have also caused serious problems for agriculture, underground water, and monuments and buildings in cities, as well as posing a threat to human health. 'We seem to forget that using the air as a vehicle for pollutants-using it for the disposal of wastes-doesn't cost anything. But it costs a lot to try to repair all the damage,' he says. 'This is what happened to our waters, and we needed 50 million francs to clean them up. Lake Geneva (Lac Léman) is still on the brink of ruin.'

\section{Lessons}

All is not lost yet, however, according to both Goeldlin and Martin. They believe valuable lessons will be learned from the Swiss experience. But they both hope other nations will attack the problem quickly, because Switzer- land cannot continue to tackle it alone. "The most important thing for a lot of European countries is to acknowledge that automobile exhausts are a very relevant source,' Dr Martin says. 'The fact that nitric oxides (from automobile exhausts) aren't being discussed extensively in some countries, is due to their higher rate of sulphur dioxide emissions. So I think: if we want European countries to look at our example, they should look at the effects of nitric oxide.'

Professor Goeldlin adds: 'Other countries should learn that [our] country is [currently] taking unilateral measures, even though we know perfectly well that a very important part of the acidification is being imported into Switzerland. So this should be... a stimulating model, putting pressure on other governments to feel solidarity with us.'

Both men believe that continued public pressure and information on the problem will push governments into action. They also believe that the Swiss experience will amplify international concern for the environment. 'We have to call the situation very, very bad,' says Dr Martin. 'But if I look globally at the whole situation, maybe the Waldsterben helps us in the sense that people will start getting more conscious of the environment,' adding: 'maybe we will have, in the next 20 or 30 years, air that is better than we have now.'

THOMAS W. NETTER
IUCN Press Service
World Conservation Centre
Avenue du Mont-Blanc
1196 Gland, Switzerland.

THOMAS W. NETTER CN Press Service 1196 Gland, Switzerland.

\title{
Conservation of Virgin Forests and Woodpeckers in Sweden
}

We are delighted to note, from the Council of Europe's ever-informative Newsletter-Nature (No. 85/4), that Sweden is taking a lead in the following two items that should interconnect vividly in Nature-loving environmentalists' minds:

Protection will be afforded to three large tracts of virgin mountain forest in the Storuman area of northern-central Sweden. This decision by the Government puts an end to a two-years-old conflict between the Swedish National Environment Protection Board and the Directorate of Crown Forests. The latter administers $85 \%$ of the country's 'prealpine' forest, which remains unexploited and is particularly precious to the cause of virgin forest conservation in Sweden. Out of a total of 670,000 hectares of listed virgin forest, the 248,000 hectares concerned are particularly valuable. The National Swedish Environment Protection Board has also had its budget for the purchase of protected areas increased from 20 to 40 million $\mathrm{kr}$.

The Middle-spotted Woodpecker (Dendrocopos medius) has been extinct in Sweden-since 1982, its disappearance being linked to that of wooded pastureland, and hence its favourite tree, the oak (Quercus sp.). Now there are fears that the White-backed Woodpecker (Dendrocopos leucotos) will meet the same fate. Its population fell by half between 1970 and 1982, from $c a 100$ to 50 pairs, and this has occurred in areas where the population has always been relatively large. The cause is attributable to a forestry policy which favours the disappearance of non-profitable deciduous forest. The implementation of the new broadleaf woodland legislation (Newsletter 85/1) will enable this process to be reversed, and may save the White-backed Woodpecker and other species which are dependent on this kind of habitat.

The Swedish Association for the Protection of Nature, in collaboration with the Swedish National Environment Protection Board, the Directorate of Crown Forests, and a number of private landowners, intends to list and mark 250,000 old hollow trees, in order that they may be protected as an essential habitat for certain kinds of birds.

\section{People's Environmental Action for Doon Valley, India}

On 12 March 1985, just 100 days after the environmental disaster of Bhopal, an Indian Supreme Court bench headed by Justice P.N. Bhagawati gave a pioneering judgement on India's first major environmental litigation, upholding the need for conservation in the broader social interest. The public-interest litigation was filed by the citizens of Doon Valley as a part of their struggle to save this unique and fragile ecobiome of the Himalayas.* The groups involved

* See these same Authors' illustrated account of 'The Conflict over Limestone Quarrying in Doon Valley, Dehradun, India', published on pp. 131-9 of our latest issue.-Ed. in this litigation were the Rural Litigation and Entitlement Centre, The Friends of the Doon, Save Mussoorie Society, and the City Board of Mussoorie.

The Doon Valley is a distinct ecobiome in the foothills of the Himalayas. It also forms the administrative unit of Tehsil Dehradun in the State of Uttar Pradesh in India. The Valley is endowed with rich and perennial water resources that supported flourishing forests, agriculture, horticulture, and the growth of an urban settlement based on research and educational institutions. The Valley also has a rich limestone deposit in its ecologically sensitive northern part. Recently, serious conflict of interest had developed 


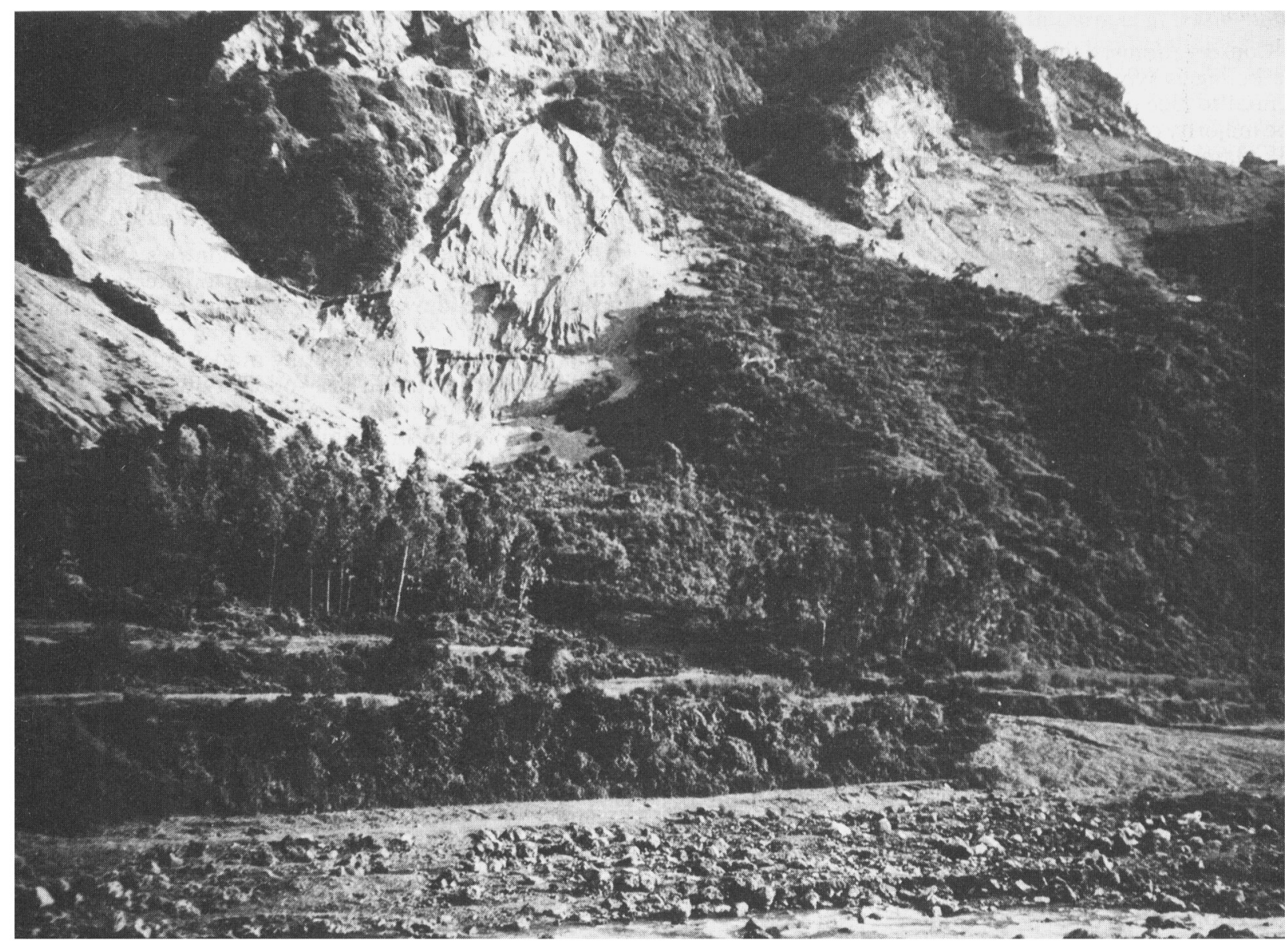

FIG. 1. Limestone quarries in the Sahasradhara area have been totally banned by the Supreme Court Order. This view shows some of the closed quarries and the in situ devastation they have created, quite apart from other ill-effects. Photo: Dr J. Bandyopadhyay.

over the quarrying of the limestone, and the case reached the Supreme Court of India as the country's first publicinterest litigation on ecological grounds.

For the limestone quarry operators, quarrying was the easy way of making quick money, as the high-grade limestone has a good market. However, for the local villagers depending on the productivity of land, for the sustainability of urban and rural water-supply schemes, for the tourism industry of Mussoorie, for the large number of schools and institutions in the Valley, and finally for the forest resources of the Valley, the quarrying was closing future options for development and even survival. Reckless destruction of the hillslopes through quarrying, totally destabilizes the hydrological balance of the Valley on which much bigger economic activities depend. Further, the limestone-based industries pollute the closed Valley with foul dust, transforming the serene Doon Valley into a 'gas chamber'. The citizens have also filed a public-interest litigation in the local court against the polluting industries.

In the 12 March 1985 judgement the Supreme Court has allowed quarrying to be continued in only 7 out of 60 quarries. Fifty-three mines have been closed, making rehabilitation a possibility (Fig. 1). The citizens are now active in planning another development for the Doon Valley which is sustainable, just, and based on democratic processes. To evolve a citizens' prescription for future devel- opment in the Doon Valley, the citizens' action groups quickly planned to hold a 2-days' symposium on 'Development and Environment of Doon Valley: Perspective for 2001 '.

In the contemporary reality of rapid environmental degradation, such citizens' participation in environmental action provides a new hope that has been rekindled in India by the Supreme Court judgement. $\dagger$

\section{VANDANa SHIVA}

Doon Valley Ecosystems Project 105 Rajpur Road

Dehradun 248001

India,

\&

JAYANTA BANDYOPADHYAY Indian Institute of Management Bangalore 560076

India.

$\uparrow$ This Supreme Court judgment has been widely acclaimed as 'historic' and 'landmark' in the Indian press-as exemplified by instances we have been sent in English from The Times of India (New Delhi, 14 March 1985), The Himachal Times (Dehradun, 15 March 1985), Indian Express (New Delhi, 18 March 1985), and The Statesman (New Delhi, 20 March 1985). - Ed. 